\title{
WUJUD PILIHAN BAHASA DALAM RANAH KELUARGA PADA MASYARAKAT PERUMAHAN DI KOTA PURBALINGGA
}

\author{
Pramika Wardhani $^{1 \bowtie}$, Mimi Mulyani ${ }^{2}$, Fathur Rokhman ${ }^{3}$ \\ Prodi Pendidikan Bahasa Indonesia Pascasarjana \\ Universitas Negeri Semarang, Indonesia
}

\begin{abstract}
The diversity of languages spoken by the community in Purbalingga City presents the existence of dwuka and multilingual community. These conditions led to the choice of language used by the people of Purbalingga especially in residential areas. The purpose of this study is to describe the form of choice of language used in the family realm. Data using libat method is competent, recording, and record. Data analysis in this research using method. With HBs (narrowing technique). Based on the speech of the people who live in Purbalingga City Housing, the result of research is the form of choice of language (1) single language, which includes indonesian language of nonformal and ngoko varieties; (2) code switching; and (3) code mixing.
\end{abstract}

keywords: choice of leanguage, family realm, residential community.

\section{Abstrak}

Keberagaman bahasa yang digunakan masyarakat tutur di Kota Purbalingga mempresentasikan adanya masyarakat dwibahasa maupun multibahasa. Kondisi tersebut memunculkan adanya pilihan bahasa yang digunakan oleh masyarakat Kota Purbalingga khususnya yang tinggal di perumahan. Tujuan penelitian ini adalah untuk mendeskripsikan wujud pilihan bahasa yang digunakan dalam ranah keluarga. Data dikumpulkan dengan metode simak dilanjutkan dengan teknik simak bebas libat cakap, rekam, dan catat. Analisis data dalam penelitian ini menggunakan metode padan dengan teknik dasar pilah unsur penentu (PUP) dan teknik lanjutan teknik hubung banding (HBB). Berdasarkan tuturan masyarakat yang tinggal di Perumahan Kota Purbalingga, diperoleh hasil penelitian wujud pilihan bahasa berupa (1) tunggal bahasa, yang meliputi bahasa Indonesia ragam nonformal dan bahasa Jawa ragam ngoko; (2) alih kode; serta (3) campur kode.

kata kunci: pilihan bahasa, ranah keluarga, masyarakat perumahan.

\section{PENDAHULUAN}

Masyarakat Indonesia adalah masyarakat yang multikultural. Terdapat beragam bahasa yang digunakan dalam komunikasi antaranggota masyarakatnya. Bahasa menjadi alat komunikasi, selain itu, bahasa menjadi cermin kepribadian seseorang. Bahkan bahasa dapat menjadi cermin karakter bangsa. Ungkapan kepribadian seseorang yang perlu dikembangkan adalah ungkapan kepribadian yang baik, benar, dan santun sehingga mencerminkan budi pekerti yang baik (Pranowo, 2009). Oleh karena itu, bahasa memiliki peran yang penting untuk dilestarikan serta menarik untuk dikaji.
Lebih lanjut, Santoso (2013) menyatakan bahwa kelangsungan hidup sebuah bahasa sangat dipengaruhi oleh dinamika yang terjadi tuturan di dalam masyarakat yang bersangkutan. Pada gilirannya, nilai-nilai sosial budaya yang hidup dan berkembang tersebut ikut menentukan realisasi bentuk-bentuk bahasa itu sendiri, termasuk pemilihan kode dan kesantunan dalam bertindak.

$$
\text { Dalam masyarakat }
$$
multibahasa tersedia berbagai kode, baik berupa bahasa, dialek, variasi, dan gaya untuk digunakan dalam interaksi sosial. Terjadinya kodekode tersebut, anggota masyarakat akan memilih kode yang tersedia sesuai dengan faktor-faktor yang mempengaruhinya. Dalam interaksi 
sehari-hari, anggota masyarakat secara konstan mengubah variasi penggunaan bahasanya (Rokhman 2013).

$$
\text { Yuniawan }
$$

menyatakan pada dasarnya pemakaian bahasa dalam masyarakat tidaklah monolitis, melainkan bervariasi. Pernyataan tersebut dapat diartikan bahwa bahasa atau bahasabahasa yang dimiliki oleh satu masyarakat tutur dalam khazanah bahasanya selalu memiliki variasi karena bahasa yang hidup dalam masyarakat selalu digunakan dalam peran-peran sosial tempat penggunaan bahasa atau variasi pahasa itu.

Strategi pemilihan bahasa menunjukkan keberagaman bahasa pada masyarakat tutur. Keberagaman penggunaan bahasa disebabkan oleh perbedaan penutur, kegiatan atau interaksi sosial, dan tujuan tutur. Setiap penutur dalam masyarakat multibahasa melakukan pemilihan bahasa untuk menentukan bahasa yang akan digunakan dalam berkomunikasi (Apriliyani dan Rokhman 2016).

Pilihan bahasa terjadi akibat kehadiran dwibahasawan. Dwibahasawan dapat memunculkan pilihan bahasa dalam bentuk alih kode maupun campur kode. Selain itu, pilihan bahasa juga terjadi karena ada tujuan yang ingin dicapai oleh penutur. Dalam penggalan tuturan di atas, pembelajar bertanya tentang konsep kata kerja pada pengajar dengan menggunakan bentuk campur kode. Kemudian, pengajar menjawab dengan bentuk alih kode. Hal ini digunakan untuk memberikan pemahaman mitra tutur tentang topik yang dibicarakan. Dengan demikian, pilihan bahasa terjadi akibat faktor partisipan dan tujuan tuturan (Fasold,
2013; Fishman, 2013; Widianto dan Zulaeha, 2016).

Pilihan bahasa terletak pada konteks situasi yang digunakan dalam komunikasi. Situasi yang dimaksud menyangkut dua hal yakni latar sosial dan latar kultural. Latar sosial berkaitan dengan prestise atau nilai lebih pada suatu ragam bahasa ketika digunakan dalam peristiwa tutur oleh penutur, dan latar kultural berkaitan dengan unggah-ungguh dan pengetahuan penutur terhadap budaya pada suatu masyarakattutur (Sholihatin 2008 dan Kholidah 2017).

Masyarakat tutur di Kota Purbalingga khususnya yang bermukim di perumahan merupakan seorang dwibahasawan yang sekurang-kurangnya memiliki dua bahasa yang digunakan untuk berkomunikasi. Hal ini dikarenakan faktor kemajemukan latar belakang masyarakat yang tinggal di perumahan Kota Purbalingga. Bahasa mayoritas masyarakat Purbalingga adalah dialek Banyumas yang terkenal dengan istilah ngapakngapak. Bahkan ada kelompok masyarakat yang sangat loyal dengan dialek Banyumas membuat istilah "ora ngapak ora kepenak" tidak berbicara dengan bahasa ngapak maka tidak enak. Akan tetapi berlakukah hal tersebut pada masyarakat yang tinggal di perumahan? Hal tersebut menjadi menarik untuk diteliti.

Alamsyah, Taib, Azwardi, dan Idham (2011) melakukan penelitian dengan judul "Pemilihan bahasa Indonesia sebagai Bahasa Pertama Anak dalam Keluarga Masyarakat Aceh Penutur Bahasa Aceh di Nanggroe Aceh Darussalam". Peneliti tersebut membahas adanya faktor-faktor yang 
menyebabkan anak penutur Aceh untuk memilih bahasa Indonesia sebagai bahasa pertama pada ranah keluarga di Nanggroe Aceh Darussalam. Hasil penelitian ini menunjukkan bahwa ada beberapa faktor yang memengaruhi pemilihan bahasa tersebut, antara lain, memudahkan anak mengikuti pelajaran di sekolah, anak lebih mudah dalam bergaul, bahasa Indonesia digunakan oleh masyarakat secara dominan, memudahkan anak berkomunikasi dengan orang lain, bahasa Indonesia memiliki nilai 'lebih' dibandingkan bahasa Aceh, pengaruh lingkungan tempat tinggal, terkesan lebih modern, lebih trendi dan keren, dianggap sebagai simbol kemapanan dan kemajuan, menetralisasi perbedaan dialek bahasa Aceh.

Penelitian yang relevan dilakukan oleh Dweik dan Hanadi (2015) dalam artikel jurnal internasional berjudul "Language Choice and Language Attitudes in a Multilingual Arab Canadian Community: Quebec-Canada: a Sociolinguistic Study”. Menyimpulkan masyarakat Arab yang tinggal di Kanada tetap menggunakan bahasa Arab mereka dalam ranah rumah dan dengan anggota keluarga, di tempat ibadah dan saat mendengarkan radio, tetapi pada saat mereka mengunjungi kantor pemerintahan Kanada mereka menggunakan bahasa Perancis atau Inggris. (2015) juga telah melakukan penelitian berjudul "Can Code Switching Enhance Learners, Academic Achievement?" menemukan bahwa alih kode dalam pembelajaran dapat meningkatkan prestasi peserta didik. Dalam ranah pendidikan, beralihnya kode dari bahasa ibu ke bahasa Inggris sangat mendukung terjadinya peningkatan prestasi didik. Hal ini diyakini bahwa peserta didik akan terlibat aktif dalam pembelajaran dan dapat memahami materi pelajaran dengan baik.

Penelitian terkait juga dilakukan Widianto dan Zulaeha (2016) dengan judul "Pilihan Bahasa dalam Interaksi Pembelajaran Bahasa Indonesia bagi Penutur Asing (BIPA)". Penelitian tersebut merupakan kajian pilihan bahasa yang digunakan penutur asing dalam interaksi pembelajaran. Temuan dalam penelitian Widianto dan Zulaeha adalah variasi tunggal bahasa, alih kode, dan campur kode di ranah pendidikan perguruan tinggi.

Selanjutnya pada tahun 2016, Apriliyani dan Rokhman melakukan penelitian berjudul "Strategi Pilihan Bahasa Pengusaha Industri Banyumas". Kajian penelitian ini berupa strategi pilihan bahasa pengusaha industri. Hasil temuannya berupa wujud pilihan bahasa pengusaha industri yang ditemukan adalah tunggal bahasa,alih kode, dan campur kode. Strategi pilihan bahasa dan faktor yang memengaruhi pilihan bahasa.

Tidak jauh berbeda dengan penelitian yang dilakukan Kholidah dan Haryadi (2017) berjudul "Wujud Pilihan Kode Tutur Mahasiswa Aceh pada Ranah Pergaulan di Semarang”. Kajian penelitian ini adalah tuturan yang digunakan oleh mahasiswa Aceh yang bermukim di Semarang. Berdasasrkan tuturan mahasiswa Aceh, diperoleh hasil penelitian wujud pilihan kode berupa (1) tunggal bahasa, yang meliputi bahasa Indonesia nonformal, bahasa Jawa 
ngoko, dan bahasa Aceh; (2) alih kode; serta (3) campur kode.

Sesuai dengan penelitian yang telah dilakukan, pilihan bahasa diperlukan oleh masyarakat tutur di perumahan Kota Purbalingga untuk berkomunikasi sekalipun dalam ranah keluarga. Pilihan kode adalah kondisi seseorang dalam masyarakat dwibahasa atau multibahasa yang berbicara dua bahasa atau lebih dan harus memilih yang mana yang harus digunakan (Fasold, 1984).

Ada beberapa faktor yang memengaruhi seseorang dalam menggunakan pilihan bahasa. Faktorfaktor tersebut antara lain (1) partisipan (mitra tutur), terkait dengan penguasaan bahasa atau kecakapan, status sosial ekonomi, usia, jenis kelamin, kedudukan, pendidikan, latar belakang etnis, hubungan kekerabatan, keakraban, hubungan kekuasaan, dan sikap terhadap bahasa; (2) situasi komunikasi, terkait dengan jenis kosakata, tempat, tingkat keresmian situasi, dan kehadiran dwibahasawan atau ekabahasawan; (3) isi pembicaraan, terkait dengan topik; serta (4) fungsi interaksi, terkait dengan tujuan menaikkan status, menciptakan jarak sosial, mengucilkan seseorang, dan meminta atau memohon (Ervin-Tripp, 1977; Mutmainah, 2008).

Menurut Sumarsono (2004) ada tiga kategori pilihan kode Pertama, dengan memilih satu variasi dari bahasa yang sama atau disebut dengan tunggal bahasa (intra language variation). Kedua, dengan melakukan alih kode (code switching), artinya menggunakan satu bahasa pada satu keperluan dan menggunakan bahasa yang lain pada keperluan lain dalam satu peristiwa komunikasi. Ketiga, dengan melakukan campur kode (code mixing) artinya menggunakan satu bahasa tertentu dengan bercampur serpihan-serpihan dari bahasa lain. Tiga kategori pilihan kode tersebut sangat berpotensi muncul di dalam tuturan masyarakat tutur di Perumahan Kota Purbalingga. Tiga kategori tersebut merupakan senjata untuk selalu muncul dalam komunikasi (Wardhaugh, 2010 dan Rokhman, 2013).

Lebih lanjut mengenai alih kode dan campur kode menurut ahli sosiolinguistik, ada tiga jenis pilihan bahasa yang biasa dikenal dalam kajian sosiolinguistik (Sumarsono dan Partana, 2002). Jenis pilihan bahasa yang pertama yakni alih kode. Kode adalah istilah netral yang dapat mengacu pada bahasa, dialek, sosiolek atau ragam bahasa. Jenis pilihan bahasa yang kedua adalah campur kode. Seperti yang diungkapkan dalam Santoso, Mardikantoro, \& Pudjitriherwanti, (2011) istilah kode dipakai untuk menyebut salah satu varian di dalam hierarki kebahasaan, sehingga selain kode yang mengacu kepada bahasa (seperti bahasa Inggris, Indonesia, dsb), juga mengacu kepada variasa bahasa, seperti varian regional (bahasa Jawa dialek Banyumas, Jogja-Solo, Surabaya), juga variasi sosial atau sosiolek (bahasa Jawa halus dan karma). Varian ragam yang dirangkum dalam laras bahasa.

Campur kode ini serupa dengan apa yang dahulu pernah disebut interferensi dari bahasa yang satu ke bahasa yang lain. Dalam campur kode, penutur menyelipkan unsur-unsur bahasa lain ketika sedang memakai bahasa tertentu. Unsur-unsur yang diambil dari bahasa lain tersebut seringkali berwujud kata-kata, tetapi dapat juga 
berwujud frasa atau kelompok kata. Jika berwujud kata, biasanya gejala itu disebut peminjaman. Jenis pilihan bahasa ketiga adalah variasi dalam bahasa yang sama yakni dalam satu bahasa, penutur dapat menggunakannya secara bervariasi. Masalah yang diungkap dalam penelitian ini terkait dengan wujud pilihan bahasa dalam ranah keluarga pada masyarakat permumahan di Kota Purbalingga. Tujuan dari penelitian ini adalah mendeskripsikan wujud pilihan bahasa dalam ranah keluarga pada masyarakat permumahan di Kota Purbalingga.

\section{TEORI SOSIOLINGUISTIK}

hubungan

Sosiolinguistik mengkaji

antara bahasa dan masyarakat yang mengaitkan dua bidang yang dapat dikaji secara terpisah, yakni struktur formal bahasa oleh linguistik dan struktur masyarakat oleh sosiologi (Wardhaugh 1986:4 dan Holmes 1992:1). Bahasa dalam kajian sosiolinguistik tidak didekati sebagai bahasa dalam kajian linguistik teoretis, melainkan didekati sebagai sarana interaksi dalam masyarakat.

Berkaitan dengan hal tersebut, konferensi sosiolinguistik yang pertama di University of California, Los Angeles tahun 1964 telah merumuskan adanya tujuh dimensi dalam penelitian sosiolinguistik, yaitu (1) identitas sosial penutur, (2) identitas sosial peserta tutur, (3) lingkungan sosial, (4) analisis sinkronik dan diakronik dari dialek sosial, (5) penilaian sosial yang berbeda oleh penutur akan bentuk-bentuk ujaran, (6) tingkatan variasi linguistik, dan (7) penerapan praktis penelitian sosiolinguistik (Dittmar 1976:128).

Selanjutnya diperkuat oleh Nababan (1986) yang menyederhanakan ruang lingkup studi sosiolinguistik menjadi tiga aspek yaitu (1) mengkaji pemakaian bahasa dalam konteks sosial dan budaya, (2) menghubungakn faktorfaktor kebahasaan dan ragam bahasa dengan situasi serta faktor sosial budaya, (3) mengkaji fungsi - fungsi sosial penggunaan bahasa dalam masyarakat. Dari segi kehidupan bermasyarakat, kajian sosiolinguistik memang terkait dengan nilai-nilai budaya masyarakat, termasuk nilainilai ketika dia menggunakan bahasa. Nilai selalu terkait dengan apa yang baik dan apa yang tidak baik yang diwujudkan dalam kaidah-kaidah yang dipatuhi oleh warga masyarakat.

\section{KEDWIBAHASAAN}

Kelompok masyarakat yang memakai dua bahasa atau lebih dalam melakukan komunikasi disebut masyarakat yang berdwibahasa atau multilingual. Menurut Tarigan (1989:2) kedwibahasaan dipandang sebagai perihal pemakaian dua bahasa (seperti bahasa daerah di samping bahasa nasional). Untuk dapat menggunakan dua bahasa itu, seseorang harus benar-benar menguasai (1) bahasa ibu sebagai bahasa pertama, dan (2) bahasa lain sebagai bahasa kedua.

Haugen (dalam Suwito 1991:49) mengemukakan bahwa kedwibahasaan adalah tahu dua bahasa, yaitu seorang dwibahasawan tidak harus menguasai secara aktif dua bahasa, tetapi cukup apabila hanya mengetahui secara pasif dua 
bahasa itu. Pilihan pemakaian bahasa pada masyarakat dwibahasa atau multibahasa memiliki beberapa kecenderungan, antara lain adanya saling mempengaruhi antarbahasa dan adanya gejala-gejala bahasa yang disebut alih kode akibat dari pilihan pemakaian bahasa tersebut (Poedjosoedarmo 1978:28).

Pengertian kedwibahasaan selalu berkembang mulai dari pengertian yang ketat sampai kepada pengertian yang longgar. Bloomfiel dalam bukunya Language (1933) memberikan batasan kedwibahasaan sebagai gejala penguasaan bahasa seperti penutur sejati (native speaker). Batasan ini mengimplikasikan pengertian bahwa seorang dwibahasawan adalah orang yang menguasai dua bahasa dengan sama baiknya (Rokhman 2014:19).

Berkaitan dengan pengertian yang longgar, Macnmara (dalam Rokhman 2014: 20) mengemukakan kedwibahasaan itu mengacu kepada pemilikan sekurang-kurangnya B1 dan B2, meskipun kemampuan dalam B2 hanya sampai batas minimal. Hal tersebut menguatkan pendapat Haugen yang telah disebutkan sebelumnya bahwa seorang dwibahasawan tidak perlu menguasai B2 secara aktif produktif sebagaimana dituntut oleh Bloomfield, melainkan cukup apabila ia memiliki kemampuan reseptif B2.

\section{PILIHAN BAHASA}

Dalam masyarakat multibahasa tersedia berbagai kode, baik berupa bahasa, dialek, variasi, dan gaya untuk digunakan dalam interaksi sosial. Dengan terjadinya kode-kode tersebut, anggota masyarakat akan memilih kode yang tersedia sesuai dengan faktor-faktor yang mempengaruhinya. Dalam interaksi sehari-hari, anggota masyarakat secara konstan mengubah variasi penggunaan bahasanya (Rokhman 2013:26).

Berbicara mengenai pilihan bahasa, hal yang pertama muncul adalah seluruh bahasa yang berkembang dalam masyarakat atau bahkan bahasa yang dikuasai oleh seorang individu. Pilihan bahasa merupakan sesuatu yang dapat dipandang sebagai masalah yang dihadapi masyarakat yang tinggal diantara interaksi dua bahasa atau lebih. Pilihan bahasa sendiri dapat diartikan sebagai kecenderungan pemakaian satu bahasa di antara beberapa bahasa yang berkembang di suatu masyarakat bahasa.

\section{ALIH KODE}

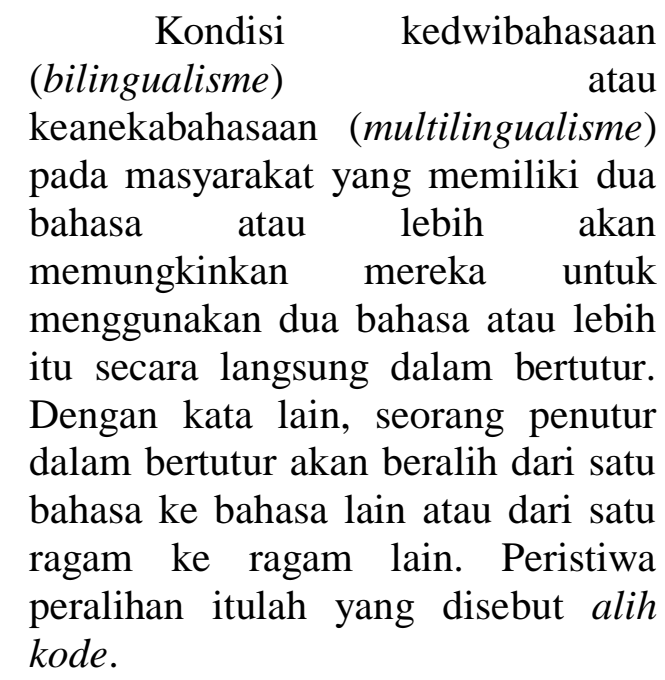

Suwito dalam (Chaer 2004:72-74) menjelaskan bahwa alih kode merupakan peristiwa kebahasaan yang disebabkan oleh faktor-faktor luar bahasa, yaitu penutur, lawan tutur, hadirnya orang ketiga dalam tuturan, keinginan membangkitkan rasa humor, dan sekedar bergengsi. Hal tersebut sesuai dengan Poedjosoedarmo (1978) yang berpendapat bahwa ada 
beberapa komponen yang terlibat dalam peristiwa alih kode. Komponen-komponen itu adalah (1) bahasa sebagai komponen utama, (2) variasi bahasa, (3) ragam, (4) dialek, (5) register, (6) tema atau pokok pembicaraan.

Selain itu, alih kode juga memiliki ciri-ciri (1) alih kode merupakan penggunaan dua bahasa atau dua variasi secara bergantian, yang masing-masing bahasa atau variasinya itu menunjukkan fungsinya masing-masing, (2) alih kode ditandai dua hal, yaitu masingmasing bhasa masih mendukung fungsi tersendiri sesuai dengan konteksnya, (3) alih kode terjadi pada masyarakat dwilingual yang mengenal variasi bahasanya, dan (4) alih kode terjadi pada seorang penutur dwibahasawan.

\section{CAMPUR KODE}

Aspek lain dari saling ketergantungan bahasa pada multilingual adalah terjadinya peristiwa campur kode. Nababan (1993:63) menyatakan bahwa campur kode adalah suatu keadaan dimana seseorang mencampur dua bahasa atau lebih bahasa atau ragam bahasa dalam suatu tindak bahasa (speech act) tanpa ada sesuatu di dalam situasi berbahasa itu yang menuntut percampuran bahasa dan dalam keadaan ini yang ada adalah kesantaian penutur atau kebiasaan yang dituruti.

Campur kode terjadi apabila dalam suatu peristiwa tutur, klausaklausa maupun frase-frase yang digunakan terdiri atas klausa/frase campuran dan masing-masing tidak lagi mendukung fungsi sendirisendiri. Misalnya, seorang penutur berbahasa Indonesia menyelipkan serpihan bahsa daerahnya ke dalam bahasa Indonesia yang digunakan. Campur kode disebabkan oleh beberapa faktor, yaitu identifikasi peranan adalah registal dan edukasional. Identifikasi ragam ditentukan oleh bahasa2 dimana penutur melakukan campur kode yang menempatkan dia di dalam hierarki status sosialnya, sedangkan keinginan menjelaskan dan menafsirkan tampaknya karena campur kode juga menandai sikap hubungannya terhadap orang lain dan sikap serta orang lain terhadapnya (Suwito 1983:77).

\section{METODE PENELITIAN}

Terdapat dua pendekatan yang digunakan dalam penelitian ini, yaitu pendekatan teoretis dan pendekatan metodologis. Pendekatan teoretis yang digunakan dalam penelitian ini adalah pendekatan sosiolinguistik. Artinya, data dianalisis dengan kajian ilmu sosiolinguistik. Hal ini bertujuan untuk mendeskripsikan data melalui paradigma ilmu sosiolinguistik.

Ada beberapa teknik pengumpulan data yang digunakan dalam penelitian ini. Teknik tersebut disesuaikan dengan metode penelitian yang digunakan. Dalam metode simak, terdapat dua jenis dalam teknik simak, yaitu teknik dasar dan teknik lanjutan. Teknik dasar berupa teknik sadap/penyadapan, yaitu peneliti menyadap penggunaan bahasa seseorang. Adapun teknik lanjutan dalam teknik simak ialah simak bebas libat cakap (SBLC), rekam, catat, dan wawancara.

Data yang telah didapat diuji keabsahannya menggunakan teknik triangulasi. Kemudian, data tersebut 
dianalisis menggunakan teknik pilah unsur penentu (PUP). Teknik tersebut merupakan teknik dasar dari metode padan. Adapun teknik lanjutan yang digunakan adalah teknik hubung banding menyamakan (HBS) dan teknik hubung banding memperbedakan (HBB). Setelah data dianalisis, data disajikan secara informal. Penyajian data secara informal dapat dilakukan dengan cara menggunakan kata-kata biasa. Penyajian tersebut berbentuk deskriptif dan menggunakan terminologi yang bersifat teknis.

\section{HASIL DAN PEMBAHASAN}

\section{Wujud Pilihan Bahasa dalam Ranah Keluarga pada Masyarakat Perumahan di Kota Purbalingga}

Kode tutur yang dipilih oleh masyarakat di perumahan Kota Purbalingga memunculkan penggunaan bahasa yang menarik. Hal ini terjadi karena mereka adalah dwibahasawan, bahkan multibahasawan. Keadaan tersebut merupakan salah satu penyebab munculnya pilihan kode tutur dalam tuturan masyarakat perumahan di Kota Purbalingga. Adapun wujud pilihan kode yang muncul dalam tuturan masyarakat perumahan di Kota Purbalingga pada ranah keluarga adalah tunggal bahasa, alih kode, dan campur kode.

\section{Tunggal Bahasa}

Tunggal bahasa yang muncul pada tuturan masyarakat perumahan di Kota Purbalingga adalah bahasa Indonesia ragam nonformal dan bahasa Jawa ngoko. Tunggal bahasa Indonesia ragam nonformal digunakan oleh keluarga pegawai baik guru non PNS, PNS, pegawai

98 | Jurnal Kredo Vol. 1 No. 2 April 2018 puskesmas, karyawan swasta, dan pegawai Bank dengan rata-rata usia 14 - 38 tahun. Sedangkan tunggal bahasa Jawa ngoko digunakan oleh keluarga pedagang dengan rata-rata usia di atas 40 tahun. Berikut ini diuraikan mengenai wujud pilihan kode berupa tunggal bahasa.

\section{a) Bahasa Indonesia Ragam Nonformal}

Bahasa Indonesia ragam nonformal merupakan variasi bahasa yang digunakan dalam situasi tidak resmi. Dalam penelitian ini bahasa Indonesia ragam nonformal digunakan dalam situasi santai antar anggota keluarga. Ciri yang tampak adalah dengan dipilihnya diksi bahasa Indonesia yang tidak baku pada tuturan masyarakat perumahan di Kota Purbalingga. Selain karena situasi yang santai, hubungan atau tingkat keakraban antarpeserta tutur juga memicu alasan penggunaan bahasa Indonesia ragam nonformal pada ranah keluarga.

(1) Konteks : Percakapan antara adik (P1) dan kakak (P2) tentang ekstrakurikuler panahan yang diikuti oleh kakak (keluarga guru).

P1: Mas udah ekstra?

'Mas sudah ekstra?'

P2 : Mulai minggu depan kayaknya, Gar

'mulai minggu depan sepertinya, Gar'

P1 : mamas dianter papa apa mama?

'mamas diantar papa atau mama?

P2 : emang kenapa Gar, nanya gitu ?

'memangnya kenapa Gar, bertanya seperti itu?

P1 : Tegar ikut ya mas 'tegar ikut ya mas' 
Peristiwa tutur (1) terjadi di rumah - perumahan Griya Perwira Asri. Peristiwa tutur tersebut terjadi antara adik (P1) sebagai penutur dan kakak (P2) sebagai mitra tutur tentang ekstra panahan. Penggalan tuturan tersebut terdapat adanya tunggal bahasa berupa bahasa Indonesia ragam tidak baku/nonformal. Bahasa Indonesia ragam nonformal tersebut dapat diidentifikasi melalui wujud kata/frasa yang dipilih atau digunakan oleh P1 dan P2 dalam berkomunikasi. Pilihan tunggal bahasa tersebut dapat dilihat dari penggalan tuturan yang diucapkan oleh P1, 'mas udah ekstra?', mamas dianter papa apa mama?' Terdapat kata 'udah', 'dianter', dan 'apa' dalam penggalan tuturan tersebut. Kata tersebut merupakan bentuk bahasa ragam nonformal dari kata 'sudah', 'diantar', dan 'atau'. Selain itu, P2 juga menggunakan bahasa Indonesia ragam nonformal dalam tuturan berikut 'mulai minggu depan kayaknya Gar' dan 'emang kenapa Gar nanya gitu'. Apabila dalam bentuk bahasa Indonesia ragam formal adalah 'kayaknya' menjadi 'sepertinya'. Tunggal kode berbentuk frasa yang dilakukan oleh P2 'emang kenapa Gar nanya gitu' menjadi 'memangnya kenapa Gar bertanya seperti itu?'. Penggalan tuturan tersebut menunjukan bukti adanya tunggal bahasa berupa bahasa Indonesia ragam nonformal dalam tuturan masyarakat perumahan dalam ranah keluarga di Kota Purbalingga.

(2) Konteks : Percakapan antara Ibu (P1) dan anak (P2) sedang mengerjakan kemandirian anak untuk mencuci sepatu sendiri. (keluarga guru)
P1 : Mas Danu, sepatunya cuci dulu mumpung Mingguan, Mamah nggak mau nyuciin, ya!

'Mas Danu, sepatunya dicuci dulu mumpung hari minggu, Mama tidak mau mencucikan, ya!'

P2 : iya, Mah, ntar abis Psan 'Iya, Mah, sebentar setelah bermain PS'.

P1 : Mas Danu, cuci sekarang! 'mas Danu, cuci sekarang!'

P2 : mamah jangan galak-galak Mah 'mama jangan galak-galak Ma'

P1 : kalau mamah nggak galak kamu nggak ndengerin sih.

'kalau mamah tidak galak kamu tidak mendengarkan sih'

Peristiwa tutur (2) terjadi di ranah rumah di perumahan Grand Safira. Percakapan tersebut terjadi antara Ibu (P1) sebagai penutur yang telah terbiasa menggunakan bahasa Indonesia saat mengajar dan anak (P2) sebagai mitra tutur. Keluarga ini terbiasa menggunakan bahasa Indonesia sebagai bahasa sehari-hari karena lebih mudah digunakan dalam berkomunikasi walau aksen bahasa Jawa masih terasa.

Penggunaan bahasa Indonesia ragam nonformal terlihat pada tuturan P1 yakni 'Mas Danu, sepatunya cuci dulu mumpung Mingguan, Mamah nggak mau nyuciin, ya!'. Terdapat kata 'nggak' dan 'nyuciin' dalam penggalan tuturan tersebut. Kata tersebut merupakan bentuk bahasa Indonesia ragam nonformal dari kata 'tidak' dan frasa 'mencucikan'. Penggunaan bahasa Indonesia ragam nonformal pada tuturan P2 yakni 'iya, Mah, ntar abis Psan'. Terdapat kalimat 'ntar abis Psan' yang seharusnya 'sebentar, setelah bermain PS.' 


\section{b) Bahasa Jawa Ragam Ngoko}

Bahasa Jawa ngoko

digunakan pada suasana santai dan dalam hubungan yang sudah akrab antara penutur dan mitra tutur dalam bertutur. Tunggal bahasa dalam bentuk bahasa Jawa ngoko juga ditemukan dalam tuturan masyarakat di perumahan Kota Purbalingga pada ranah keluarga. Penggalan tuturan yang merepresentasikan tunggal bahasa dalam bentuk bahasa Jawa ngoko dapat dilihat pada percakapan berikut.

(3) Konteks : percakapan suami (P1) dan istri (P2) yang akan memasak nasi goreng.

P1 : Yang, gawe sega goreng yuh! 'sayang, buat nasi goreng yuh'

P2 : nganahlah, mamas bae, aku emoh, males

'sana, mamas saja, aku tidak mau, malas.

P1 : yawis tek gawe mengko dicicipi, ya!

'ya sudah saya buat, nanti dicicipi, ya'

(4) Konteks : percakapan Ibu (P1) dengan anaknya membahas mengenai jodoh

P1 : kenangapa njaprut, Mba? 'kenapa cemberut, mba'

P2 : bu, unggal dina ketemu wong ditakoni kapan ale arep mbojo, nyong isin, $\mathrm{Bu}$, priwe kie?

'bu, setiap hari bertemu orang ditanyai kapan akan menikah, saya malu, $\mathrm{Bu}$, bagaimana ini?

Peristiwa tutur (3) dan (4)

merupakan tuturan yang terjadi di ranah keluarga yaitu keluarga pegawai swasta dan keluarga pedagang di perumahan Grand Safira. Pada peristiwa tutur tersebut, sama-sama menggunakan bahasa Jawa ngoko. Hal ini dikarenakan P1 dan P2 sama-sama menguasai bahasa Jawa ngoko dengan baik karena merupakan bahasa Ibu atau bahasa pertama masing-masing partisipan. P1 dan P2 menggunakan bahasa Jawa ngoko karena adanya kekurangan penguasaan kosakata bahasa Jawa krama pada peristiwa tutur yang memerlukan adanya bentuk tuturan yang bertingkat. Di samping itu, karena faktor kebiasaan atau budaya dari keluarga tersebut sedari kecil menggunakan bahasa Jawa ngoko.

\section{Alih Kode}

Alih kode merupakan peralihan dari bahasa yang satu ke bahasa lain. Alih kode muncul dalam tuturan masyarakat perumahan dalam ranah keluarga di Kota Purbalingga .Hal ini, muncul akibat adanya partisipan dwibahasa atau multibahasa.Wujud pemilihan bahasa berupa alih kode yang muncul dalam tuturan masyarakat perumahan dalam ranah keluarga di Kota Purbalingga berupa (1) alih kode dari bahasa Jawa krama ke bahasa Jawa ngoko, (2) alih kode dari Jawa ke bahasa Indonesia, (3) bahasa Indonesia ke bahasa Jawa, dan (4) bahasa Indonesia ke bahasa Asing. Wujud pilihan bahasa berupa alih kode dapat dilihat pada penggalan tuturan berikut.

(5) Konteks : Percakapan ayah (P1) dengan anaknya (P2) yang disuruh mengambil gunting tetapi tidak tahu disimpan oleh ibunya.

P1 : Len, pendetaken gunting 'Len, ambilkan gunting'

P2 : teng pundi, Pak? 'di mana, Pak?

P1 : takok Ibu jajal 'tanya ibu coba'

P2 : Ibu ga reti, Pak 
'ibu tidak tahu, pak'

Peristiwa tutur (5) terjadi di perumahan Pepabri. Percakapn tersebut terjadi antara Ayah (P1) dengan anak (P2). Bahasa yang digunakan adalah bahasa Jawa krama dan bahasa ngoko dialek Temanggung. Penggalan peristiwa tutur tersebut, terdapat alih kode internal dari bahasa Jawa krama ke dalam bahasa Jawa ngoko. Hal ini terlihat pada tuturan yang dilakukan oleh P1, yakni 'Len, pendetaken gunting'. P2 menjawab tuturan tersebut menggunakan bahasa bahasa Jawa krama 'teng pundi, Pak?'. Pada saat P1 beralih menggunakan bahasa Jawa ngoko, $P 2$ juga melakukan peralihan bahasa Jawa ngoko 'Ibu ga reti, Pak'. Alih kode ini dilakukan oleh P1 agar tuturan selanjutnya menggunakan bahasa Jawa ngoko. Hal ini dikarenakan penguasaan kosakata bahasa Jawa krama yang kurang pada masingmasing penutur dan karena faktor situasi yang santai sehingga lebih nyaman menggunakan bahasa Jawa ragam ngoko sesuai daerah asal mereka; Temanggung.

(6) Konteks : perckapan istri (P1) dengan suami (P2) berkaitan dengan kantor baru.

P1 : piye, betah Mas, nek kantor anyar?

'bagaimana nyaman Mas? di kantor baru?'

P2 : sejauh ini cocok, Mah. 'sejauh ini cocok,Mah'

P1 :Mudah mudahan lancar semuanya ya Mas.

'mudah-mudahan lancar semuanya ya mas'

P2 : iya gak usah pindah lagi 'iya tidak perlu pindah lagi'

Peristiwa tutur (6) terjadi di perumahan Grand Safira. Percakapn tersebut terjadi antara istri (P1) dengan suami (P2) yang baru pindah kantor. Bahasa yang digunakan adalah bahasa Jawa ngoko dialek Semarang dan bahasa Indonesia. Penggalan peristiwa tutur tersebut, terdapat alih kode dari bahasa Jawa Ngoko ke dalam bahasa Indonesia. Hal ini terlihat pada tuturan yang dilakukan oleh P1, yakni 'piye, betah Mas, nek kantor anyar?'. P2 menjawab tuturan tersebut menggunakan bahasa Indonesia dalam tuturannya. Alih kode ini dilakukan oleh P2 agar tuturan selanjutnya menggunakan bahasa Indonesia. Hal ini dikarenakan penguasaan kosakata bahasa Jawa P2 yang kurang. Dalam hal ini, P2 memilih bahasa Indonesia dalam berkomunikasi dengan $\mathrm{P} 1$.

(7) Konteks : percakapan Ibu (P1) dan anak (P2) Ibu menyuruh anak untuk segera mandi karena sudah sore.

P1 : Mas, mandi Mas!

'mas, ayo mandi mas'

P2 : ya Bu, nanti

'iya Ibu, nanti'

P1 : udah sore, Mas

'sudah sore, Mas'

P2 : iya Ibu, bentar lagi

'iya Ibu, sebentar lagi'

P1 : Mas, Ibu dah keluar tanduknya ini

'mas Ibu sudah keluar tanduknya ini'

P2 : lima menit lagi $\mathrm{Bu}$ 'lima menit lagi ya Bu'

P1 : Mas udah keluar taringnya ini

'Mas, sudah keluar taringnya ini'

P2 : Nggih, Bu sekedap malih

'Iya, Bu sebentar lagi'

P1 : nak, nggih, yo ndang to!

'kalau iya ya cepat-cepat mas' 
Peristiwa tutur (7) terjadi di perumahan Grand Safira. Terjadi antara Ibu (P1) dan anak (P2) yang disuruh mandi karena sudah sore. Bahasa yang digunakan adalah bahasa Indonesia ragam tidak baku dan bahasa Jawa. P2 beralih menggunakan bahasa Jawa 'nggih, Bu sekedap malih' sebenarnya adalah untuk membujuk Ibunya agar dibolehkan untuk menunda waktu mandi. P2 membalas menggunakan bahasa Jawa 'nak, nggih, yo ndang to, Mas' untuk menyindir anaknya supaya lekas mandi setelah memberi penrnyataan 'iya/nggih'.

(8) Konteks : percakapan suami (P1) dan istri (P2) yang pulang karena dompetnya ketinggalan

P1 : Mama, dompetku di mana Ayah lupa

'Mama dompetku di mana Ayah lupa'

P2 : di atas kulkas, Yah 'di atas kulkas, Ayah'

P1 : berangkat lagi ya Ma 'berangkat lagi ya, Ma'

P2 : entar pulang malem lagi? 'nanti pulang malam lagi?'

P1 : iya. Assalamuallaikum 'iya. Assalamuallaikum'

P2 : wa'allaikumsalam

'wa'allaikumsalam'

Peristiwa tutur (8) terjadi antara suami dan istri di perumahan Grand Safira. Bahasa yang digunakan adalah bahasa Indonesia dan bahasa Arab. Pengalihan bahasa Arab dalam konteks ini karena sebagai muslim memiliki kewajiban memberikan salam. Sehingga tuturan 'Assalamuallaikum' dan 'Wa'allaikumsalam' merupakan tuturan yang dilakukan oleh P1 sebagai suami terhadap istri sebagai P2 sebelum berangkat kerja.

\section{Campur Kode}

Campur kode merupakan penyisipan kode dalam kode lain. Campur kode muncul dalam tuturan masyarakat yang tinggal di perumahan saat berkomunikasi dengan anggota keluarga. Hal itu merupakam salah satu gejala adanya penutur dwibahasawan. Campur kode yang muncul adalah percampuran antara bahasa Indonesia dengan bahasa daerah maupun bahasa Asing. Selain itu, campur kode juga terdapat penyisipan pada tataran kata, frasa, baster, perulangan kata, dan klausa yang muncul dalam tuturan tersebut. Berikut penggalan tuturan masyarakat perumahan yang mengandung campur kode.

(9) Konteks : percakapan kakak (P2) dan adik (P1) mengenai aplikasi edit foto terbaru

P1 : mba udah instal aplikasi BBM baru?

'mba sudah instal aplikasi BBM baru?

P2 : belum, emang kenapa? 'belum, memangnya kenapa'

P1 : kamu harus instal mba. You can make pict sendiri!

'kamu harus instal mba. Kamu bisa membuat foto sendiri!'

P2 : oh yang kayak punya Rere kemarin itu? Entar deh coba

'oh yang seperti punya Rere kemarin? Nanti dicoba.

Peristiwa tutur (9) terjadi di perumahan Griya Perwira Asri. Bahasa yang digunakan adalah bahasa Indonesia dan bahasa Inggris. Pada tuturan antara kakak - adik yang membicarakan aplikasi terbaru BBM merupakan campur kode tataran kata dan frasa. Utamanya pada tuturan P1 'kamu harus instal mba. You can make pict sendiri!' yang apabila dalam bahasa Indonesia bermakna 'kamu bisa membuat 
gambar sendiri'. Bahasa Inggris dipilih oleh P1 karena dianggap paling tepat dapat mewakili perasaan bahagia dengan aplikasi baru BBM.

Campur kode dituturkan untuk menjelaskan kepada penutur. Campur kode lazim digunakan dalam komunikasi sehari-hari. Kemunculan campur kode didukung oleh beberapa faktor, seperti situasi, maksud tuturan, dan topik yang sedang dibicarakan. Penggalan tuturan yang mengandung campur kode seperti percakapan berikut.

(10) Konteks : percakapan Istri (P1) dan Suami (P2) mengenai rencana ke Rumah Sakit membesuk saudara.

P1 : nanti siang jadi nengok Bu Siti,

Bapak, ndak usah ikut

'nanti siang jadi membesuk

$\mathrm{Bu}$ Siti, Bapak tidak usah ikut'

$\mathrm{P} 2$ : iya udah $\mathrm{Bu}$, malahane

'Iya sudah $\mathrm{Bu}$, kebetulan'

Peristiwa tutur (10) terjadi di perumahan Pepabri, antara istri (P1) dan suami (P2). Bahasa yang digunakan adalah bahasa Indonesia dan bahasa Jawa. Pada tuturan pertama P1 menyisipkan kode bahasa Jawa 'ndak' yang dalam bahasa
Indonesia maknanya 'tidak'. Begitu juga P2 yang menyisipkan kode bahasa Jawa 'malahane' yang bermakna 'kebetulan'. Campur kode yang dilakukan oleh penutur pertama dan kedua termasuk campur kode dalam tataran kata.

\section{SIMPULAN}

Berdasarkan hasil temuan pada penelitian ini, wujud pilihan bahasa dalam ranah keluarga pada masyarakat perumahan di Kota Purbalingga berupa tunggal Bahasa, meliputi bahasa Indonesia ragam nonformal dan bahasa Jawa ngoko; alih kode; serta campur kode. Masyarakat tutur di perumahan cenderung menuturkan tunggal kode dan alih kode internal dari bahasa Jawa ngoko ke bahasa Jawa krama hal itu disebabkan oleh penggunaan bahasa dari penutur yang lebih muda kepada penutur yang lebih tua dengan hubungan anak dan orangtua. Dengan demikian masyarakat di Perumahan lebih dominan melakukan alih kode dari bahasa Jawa ngoko ke bahasa Jawa krama dengan alasan adanya partisipan yang lebih tua sehingga ingin menunjukan sikap hormat dan sopan.

\section{DAFTAR PUSTAKA}

Alamsyah, Teuku. Taib, R., Azwardi,. \& Idham, Muhammad. 2011. Pemilihan Bahasa Indonesia sebagai Bahasa Pertama Anak dalam Keluarga Masyarakat Aceh Penutur Bahasa Aceh di Nanggroe Aceh Darussalam. Jurnal Pendidikan Bahasa Melayu. 1(2): 31-44.

Apriliyani, Nurul dan Fathur Rokhman. 2016. Strategi Pilihan Bahasa Pengusaha Industri di Kecamatan Ajibarang Kabupaten Banyumas. Seloka: Jurnal Pendidikan Bahasa dan Sastra Indonesia. 5(2): 184-191. 
Darwati dan B. Wahyudi Djoko Santoso. 2017. Pilihan Kode pada Wacana Konsultasi Siswa kepada Guru di SMK Ma'arif 4 Kebumen. Seloka: Jurnal Pendidikan Bahasa dan Sastra Indonesia. 5(2): 184-191.

Kholidah, Umi dan Haryadi. 2017. Wujud Pilihan Kode Tutur Mahasiswa Aceh pada Ranah Pergaulan di Semarang. Jurnal SELOKA. 6(2): 208-217.

Mardikantoro, Hari Bakti. 2007. Pergeseran Bahasa Jawa dalam Ranah Keluarga pada Masyarakat Multibahasa di Wilayah Kabupaten Brebes. Jurnal Humaniora Volume 19 NO.1 Februari halaman 43-51.

Mardikantoro, Hari Bakti. 2012. Pilihan Bahasa Masyarakat Samin dalam Ranah Keluarga. Jurnal Humaniora. 24(3): 345-357.

Poedjoseodarmo, Soepomo. 1978. "Kode dan Alih Kode" dalam Jurnal Widyaparwa No. 22 Tahun 1982. Yogyakarta: Balai Penelitian Bahasa, halaman 1-43.

Santoso, B. W.J., Mardikantoro, H.B., \& Pudjitriherwanti, A. 2011. Artikel Penelitian, 1-20. http://journal.unnes.ac.id

Santoso, Wahyudi, Joko. 2013. Kode dan Kesantunan dalam Rapat Dinas Berspektif Gender dan Jabatan. http://journal.unnes.ac.id/

Simasuki, L., Kasanda, C., \& Smit, T. 2015. Can Code Switching Enhance Learners' Academic Achievement?. Internasional Journal of English Language Teaching. 8(2).

Widianto, Eko \& Ida Zuleha. 2016. Pilihan Bahasa dalam Interaksi Pembelajaran Bahasa Indonesia bagi Penutur Asing. Seloka: Jurnal Pendidikan Bahasa dan Sastra Indonesia. 5(2): 124-135.

Yuniawan, Tommi. 2005. Campur Kode pada Masyarakat Etnik Jawa-Sunda: Kaman Sosiolinguistik dalam Ranah Pemerintahan di Kabupaten Brebes. Jurnal HUMANIORA. 17(1): 89-99.

Dittmar, Norbert. 1976. Sociolinguistics: Goals, Approaches, and Problem. London: Bastford.

Nababan. 1993. Sosiolinguistik, Suatu Pengantar. Jakarta: Gramedia.

Rokhman, Fathur. 2013. Sosiolinguistik (Suatu Pendekatan Pembelajaran Bahasa dalam Masyarakat Multikultural). Yogyakarta: Graha Ilmu.

Sudaryanto. 2015. Metode dan Aneka Teknik Analisis Bahasa, Pengantar Penelitian Wahana Kebudayaan secara Linguistik. Yogyakarta: Sanata Dharma 
Sumarsono \& Partana. 2004. Sosiolinguistik. Jakarta: Sabda Pustaka Pelajar.

Suwito. 1985. Sosiolinguistik, Pengantar Awal. Surakarta: Henary Offset.

Wardhaugh, Ronald. 1986. An Introduction to Sociolinguistics. Oxford: BasilBlackwell.

Sholihatin, Anis. 2008. Pemilihan Kode pada Masyarakat Keturunan Arab di Noyontaan, Kota Pekalongan: Kajian Sosiolinguistik. Tesis: Universitas Diponegoro.

Rokhman, Fathur. 2003. "Pemilihan Bahasa dalam Masyarakat 